Tropical Journal of Pharmaceutical Research April 2011; 10 (2): 211-218

(C) Pharmacotherapy Group

Faculty of Pharmacy, University of Benin

Benin City, 300001 Nigeria.

All rights reserved.

Research Article

Available online at http://www.tjpr.org

\title{
Phytochemical and Antibacterial Evaluations of the Stem Bark of Newbouldia laevis against Isolates from Infected Wounds and Eyes
}

\author{
JO Akerele ${ }^{1}$, BA Ayinde ${ }^{2^{\star}}$ and J Ngiagah ${ }^{1}$ \\ ${ }^{1}$ Department of Pharmaceutical Microbiology, ${ }^{2}$ Department of Pharmacognosy, Faculty of Pharmacy, University of \\ Benin, Benin City, Nigeria.
}

\begin{abstract}
Purpose: To examine the phytochemical constituents and verify the ethnomedical claim of Newbouldia laevis (P.Beauv.) Seeman ex Bureau Bignoniaceae in treating septic wounds and eye problems.

Methods: Applying standard methods, the phytochemical constituents of the stem bark were examined while the antibacterial potentials of the methanol extract of the stem bark and its organic solvent fractions were tested on clinical bacterial isolates from infected wounds and eyes using the agar - well diffusion method. Ciprofloxacin and gentamicin were used as standard controls. The time-kill kinetics of the methanol stem bark extract and ciprofloxacin were determined using isolates of Staphyloccocus aureus.

Results: Phytochemical screening of the stem bark revealed the presence of flavonoids, tannins, saponins and alkaloids with no traces of cyanogenic glycosides. The 65 bacterial pathogens isolated included Proteus mirabilis (26.0\%) and Pseudomonas aeurginosa (17.4\%) from non-diabetic patients' wounds; Staphylococcus aureus (32.0\%) and Escherichia coli (16.0\%) from diabetic patients' wounds; Staphylococcus aureus (35.3\%) and Pseudomonas aeruginosa (35.3\%) from infected eyes. The chloroform fraction was observed to be more active on Gram- negative organisms while the aqueous fraction was more active on Gram-positive organisms. Time-kill kinetics of Staphylococcus aureus showed that the extract was bactericidal (99.9\% killing) at MIC and 2 x MIC after 24 and 3 hours, respectively.

Conclusion: The study has established that the stem bark of Newbouldia laevis has antibacterial activities against bacterial isolates from infected wounds and eyes as claimed in ethnomedicinal practice.
\end{abstract}

Keywords: Newbouldia laevis, Antibacterial, Phytochemical, Wound isolates, Eye isolates.

*Corresponding author: E-mail: baayinde@uniben.edu; baayinde01@yahoo.com 


\section{INTRODUCTION}

Newbouldia laevis Seem (Bignoniaceae) is commonly known as smooth Newbouldia or boundary tree. It is called 'Aduruku' in Hausa; 'Ogirisi' in Igbo; 'Ikhimi' in Edo and 'Akoko' in Yoruba languages ${ }^{[1]}$. It grows to a height of about 7 - 8 (up to 15) meters, more usually a shrub of 2-3 metres, many - stemmed forming clumps of gnarled branches ${ }^{[2]}$.

Newbouldia laevis is widely used in African folk medicine for the treatment of malaria and fever, stomach-ache, coughs, sexually transmitted diseases, tooth ache, breast cancer, and constipation ${ }^{[3-5]}$. In South Eastern and part of the Midwestern Nigeria, the plant is used for the treatment of septic wounds and eye problems ${ }^{[6]}$. The antimicrobial potential of methanol extract of the leaf has been reported in literature while the antiinflammatory and antimalarial activities of the root extract have also been documented ${ }^{[7,8]}$. Scientific reports on the phytochemical constituents of the plant revealed the presence of alkaloids and phenylpropanoids in the root [9], flavonoids, and tannins in the leaf ${ }^{[7]}$.

Wound infection is detrimental to wound healing which is a complex process that can be delayed by many potential factor ${ }^{[10]}$. A variety of disorders commonly affect the eye and vary in severity from mild but annoying allergic conjunctivitis to sight threatening infections ${ }^{[11]}$.

As it has been asserted that medicinal plants constitute a continuous source of new compounds with the potential to act against multi-resistant bacteria ${ }^{[12]}$, this work was aimed at investigating the antibacterial potential of the methanol extracts of the stem bark of Newbouldia laevis against isolates from infected wounds and eyes.

\section{EXPERIMENTAL}

\section{Collection and preparation of the plant material}

The stem bark of Newbouldia laevis was collected in June 2007, at Themboga, Benin City, Nigeria. The identity of the plant was authenticated by Dr. Olufemi Shasanya, a taxonomist at the Forest Research Institute of Nigeria (FRIN), lbadan. A herbarium specimen no. FHI0031505-0 was deposited at the Institute's herbarium for reference. The stem bark was cut into pieces and dried in the oven at $50-60{ }^{\circ} \mathrm{C}$ for 6 days after which they were reduced to powder form with a milling machine.

\section{Phytochemical tests}

These were carried out using standard methods ${ }^{[13,14]}$.

\section{Extraction of plant material}

About $1750 \mathrm{~g}$ of the powdered stem bark was extracted with methanol (5l) using maceration method for 72 hours. After filtration, the extract was concentrated to dryness (semi solid) using rotary evaporator. The dried extract $(25.9 \mathrm{~g}, 1.48 \%)$ was kept in the refrigerator maintained at $4^{0} \mathrm{C}$ until required.

\section{Solvent - solvent partitioning of the methanol extract}

About $8 \mathrm{~g}$ of the methanol extract of the stem bark was dissolved in methanol - water (1:1) and partitioned with chloroform (300 $\mathrm{ml} \times 3)$. The chloroform and aqueous phases obtained were separately concentrated to dryness and weighed.

\section{Sources of the microorganisms used}

Following receipt of permission from the authorities of the University of Benin Teaching Hospital, Benin City, Nigeria, wound swabs were obtained from infected wounds of diabetic and non-diabetic patients 
while eye specimens were obtained from the eye discharges of patients with eye problems at the Ophthalmology Clinic of the same hospital. All the bacterial organisms isolated were identified using conventional biochemical techniques ${ }^{[15]}$. The bacterial isolates were maintained on nutrient agar slants at $4{ }^{\circ} \mathrm{C}$ and subcultured at intervals of three weeks to ensure their viability and purity.

\section{Antibacterial assays}

\section{Preparation of the bacterial inocula}

Broth cultures of desired organisms were prepared by suspending two colonies of each organism in nutrient broth and incubated aerobically at $37{ }^{0} \mathrm{C}$ for 12 hours. Suspensions were adjusted to a turbidity of about $10^{8}$ colony forming units (cfu)/ml using 0.5 McFarland Standard for visual comparison. Hundred fold dilutions were made to yield final suspensions with approximately $10^{6} \mathrm{cfu} / \mathrm{ml}$.

\section{Screening for antibacterial activity}

By adopting a modified agar-well diffusion method ${ }^{[16]}$, the screening of the methanol extract, its organic solvent fractions, and the standard antibacterial agents were carried out. $25 \mathrm{ml}$ of sterile molten nutrient agar cooled to about $40^{\circ} \mathrm{C}$ was aseptically seeded with $100 \mu \mathrm{l}$ of the desired organism at a turbidity of approximately $10^{6} \mathrm{cfu} / \mathrm{ml}$. The seeded agar was aseptically poured into sterile Petri dishes of $8.5 \mathrm{~cm}(85 \mathrm{~mm})$ in diameter and allowed to set at room temperature.

With the aid of a sterile cork borer, four uniform wells of $7 \mathrm{~mm}$ in diameter were punched on each plate. The wells were each filled with $0.1 \mathrm{ml}$ of stock concentration to give a final srength of $10 \mathrm{mg} / \mathrm{ml}$ or $20 \mathrm{mg} / \mathrm{ml}$ of the extract; or $0.1 \mathrm{ml}$ of ciprofloxacin or gentamicin solution to give a final concentration of $10 \mu \mathrm{g} / \mathrm{ml}$ which were used as positive control. A pre-diffusion time of $1 \mathrm{~h}$ was allowed before the plates were incubated aerobically at $37{ }^{0} \mathrm{C}$ for $18-24 \mathrm{~h}$. The diameter of the zones of inhibition was measured to the nearest millimeter with a transparent millimeter rule. The effects of the chloroform and aqueous fractions were tested at $20 \mathrm{mg} / \mathrm{ml}$ concentration. The tests were carried out in replicates.

Determination of minimal inhibitory concentration (MIC) and minimal bactericidal concentration (MBC)

The modified method of [17] was employed to determine the MIC of the extract (MSE) and its aqueous fraction. Serial two-fold dilutions of $2 \mathrm{ml}$ each were made in a concentration range of 50 to $0.391 \mathrm{mg} / \mathrm{ml}$ of the extract and 25 to $1.5625 \mathrm{mg} / \mathrm{ml}$ of the aqueous fraction using double strength nutrient broth supplemented with $10 \%$ glucose. The tubes were inoculated with 100 $\mu \mathrm{l}$ of the desired organisms (at a turbidity of approximately $10^{6} \mathrm{cfu} / \mathrm{ml}$ ) and incubated aerobically at $37{ }^{\circ} \mathrm{C}$ for $18-24 \mathrm{~h}$. Microbial growth was determined by adding $20 \mu$ of phenol red $(0.2 \%)$ indicator and observing a change in colour from red to yellow when there is microbial growth. The lowest concentration that showed no change in colour was considered the MIC. The procedure was repeated using ciprofloxacin $(16-0.031 \mu \mathrm{g} / \mathrm{ml})$ and gentamicin (32 - 0.063 $\mu \mathrm{g} / \mathrm{ml}$ ) and observing the tubes for turbidity.

For MBC determination, $20 \mu \mathrm{l}$ of the liquid from each tube that showed no change in colour for the extract (MSE) and the aqueous fraction (aMSE), and turbidity for reference antibacterial agents was plated on antibacterial agent-free nutrient agar. The plates were incubated aerobically at $37{ }^{\circ} \mathrm{C}$ for $18-24 \mathrm{~h}$ and the lowest concentration that yielded no growth was recorded as the MBC.

\section{Time-kill testing}

The effect of $1 / 2 \mathrm{MIC}$, MIC and 2MIC concentrations of the methanol extract on the viability of two isolates of Staphylococcus 
aureus was examined by the Time-killing method. The isolates used were those obtained from non-diabetic and eye isolates.

The different concentrations of the MSE were prepared from a stock solution of $50 \mathrm{mg} / \mathrm{ml}$ using double strength nutrient broth. Overnight broth culture of the desired organism $(200 \mu \mathrm{l})$ was placed in contact with a specified extract concentration. Viable counts were determined at the beginning of incubation and at intervals (i.e. after 1, 2, 3, 4, 5, 6 and $24 \mathrm{~h}$ ) by withdrawing $100 \mu \mathrm{l}$ aliquots of the extract-organism mixture, in order to determine the time it took the extract to eradicate all viable cells of the organisms. The same procedures were repeated using ciproflaxin with the two organisms.

\section{Data analyses}

The diameter of zones of inhibition for antibacterial assays were expressed as mean \pm S.E.M. Simple percentage was used to analyze the distribution of bacterial isolates.

\section{RESULTS}

\section{Phytochemical constituents}

Phytochemical screening of the powdered sample of the stem bark of $N$. laevis revealed the presence of saponins, tannins, flavonoids, steroidal glycosides and alkaloids while cyanogenic glycosides and anthracene derivatives were observed to be absent.

\section{Bacterial isolates}

The clinical specimens revealed the presence of various bacterial species occurring in varying degrees in the wounds and infected eyes. In the non-diabetic patients, the bacterial organisms had Proteus mirabilis as the most predominant organism (6 out of 23 patients; $26.1 \%$ ), whereas the isolates from the diabetic patient wounds predominantly produced Staphylococcus aureus (8 cases out of 25 representing $32 \%$ ). The isolates from the infected eyes yielded Staphy. aureus and Pseudomonas aeruginosa, each constituting $35 \%$ of the 17 isolates. While Citrobacter and Providencia species were found only in the wounds of non diabetic patients, the only occurrence of Klebsiella sp. was recorded in an infected eye. The presence of Staph. aureus, Ps. aeruginosa and $P$. mirabilis was common in all the specimen sources (Table 1).

Table 1: Distribution of organisms obtained from the different sources

\begin{tabular}{|c|c|c|c|c|c|c|}
\hline \multirow[t]{2}{*}{$\begin{array}{l}\text { Bacterial } \\
\text { organism }\end{array}$} & \multicolumn{2}{|c|}{$\begin{array}{c}\text { Non- } \\
\text { diabetic } \\
\text { source }\end{array}$} & \multicolumn{2}{|c|}{$\begin{array}{c}\text { Diabetic } \\
\text { source }\end{array}$} & \multicolumn{2}{|c|}{$\begin{array}{l}\text { Eye } \\
\text { source }\end{array}$} \\
\hline & $N$ & $\begin{array}{c}F \\
(\%)\end{array}$ & $N$ & $\begin{array}{c}F \\
(\%)\end{array}$ & $N$ & $\begin{array}{c}F \\
(\%)\end{array}$ \\
\hline Citrobacter sp & 1 & 4.4 & - & - & & \\
\hline $\begin{array}{l}\text { CON } \\
\text { Staphylococc }\end{array}$ & 1 & 4.4 & - & - & 2 & 11.8 \\
\hline $\begin{array}{l}\text { us } \\
\text { Enterococcus } \\
\text { faecalis }\end{array}$ & 1 & 4.4 & 1 & 4 & - & - \\
\hline $\begin{array}{l}\text { Enterobacter } \\
\mathrm{sp}\end{array}$ & 1 & 4.4 & 3 & 12 & - & - \\
\hline $\begin{array}{l}\text { Escherichia } \\
\text { coli }\end{array}$ & 2 & 8.7 & 4 & 16 & & \\
\hline $\begin{array}{l}\text { Providencia } \\
\text { sp }\end{array}$ & 2 & 8.7 & - & - & - & - \\
\hline $\begin{array}{l}\text { Proteus } \\
\text { mirabilis }\end{array}$ & 6 & 26.1 & 3 & 12 & 2 & 11.8 \\
\hline $\begin{array}{l}\text { Proteus } \\
\text { vulgaris }\end{array}$ & 2 & 8.7 & 1 & 4 & - & - \\
\hline $\begin{array}{l}\text { Alcaligenes } \\
\mathrm{sp}\end{array}$ & & & 2 & 8 & - & - \\
\hline Staph. aureus & 3 & 13.0 & 8 & 32 & 6 & 35.3 \\
\hline Klebsiella sp & - & - & - & - & 1 & 5.9 \\
\hline $\begin{array}{l}\text { Ps. } \\
\text { aeruginosa }\end{array}$ & $\begin{array}{c}4 \\
23\end{array}$ & $\begin{array}{r}17.4 \\
100\end{array}$ & $\begin{array}{c}3 \\
25\end{array}$ & $\begin{array}{c}12 \\
100\end{array}$ & $\begin{array}{l}6 \\
17\end{array}$ & $\begin{array}{r}35.3 \\
100\end{array}$ \\
\hline
\end{tabular}

Note: $N$ = number of occurrences; $F$ = frequency; $C O N=$ coagulase negative; Staph = Staphylococcus; $P$ s = Pseudomonas; $s p=$ species

\section{Antibacterial activity of extract}

The methanol extract of the stem bark showed activity against the tested isolates except Escherichia coli and Providencia species which were obtained from the wounds of non diabetic patients but however exhibited activity against the E.coli obtained from the wound of diabetic patient. The extract was more active against Grampositive than Gram-negative organisms with Staphylococcus aureus being the most 
susceptible. The Enterobacteria species, Enterococcus feacalis, Proteus vulgaris and Klebsiella species that showed resistance to the ciprofloxacin and gentamicin were observed to be susceptible to 10 and $20 \mathrm{mg}$ of the extract. Staphylococcus. aureus obtained from the wounds of non diabetic patient and infected eyes were more susceptible to the extract than the one obtained from the wound of diabetic patient (Table 2).

The activity of the extract was concentration dependent, with the effect at $20 \mathrm{mg}$ being slightly higher than the activity at $10 \mathrm{mg}$ although not in all the organisms. The organic solvent fractions were observed to exhibit different activities on the selected icroorganisms. While the antibacterial activities were observed to increase on some bacteria, the effects were concentrated in either the chloroform or the aqueous fraction (see Table 3).

The organisms showed varying degrees of susceptibility to the extract at MIC and MBC. For some of the isolates, the same concentration of the extract that produced the MIC also was the MBC, while for others, the bactericidal concentrations was obtained at double MIC (Table 4).

For the time-killing effects of the extract on the isolates of Staph. aureus obtained from the non diabetic patient and infected eye isolates, the extract produced significant reduction in the viable cell counts of the organisms. The MIC of the isolate obtained from the wound of non diabetic patient was $6.5 \mathrm{mg} / \mathrm{ml}$. At $2 \mathrm{MIC}$, the extract completely eliminated all the viable cells of the organism in less than $6 \mathrm{~h}$ (Fig 1).

Table 2: Inhibitory effect of $N$. laevis stem bark methanol extract and standard antibacterial agents on groeth of bacterial isolates (mean \pm SD)

\begin{tabular}{lccccc}
\hline & & \multicolumn{3}{c}{ Zone of inhibition (mm) } \\
\cline { 3 - 6 } Bacterial isolate & Source & \multicolumn{2}{c}{ Extract } & Cipro & Gentam \\
& & $\mathbf{1 0 m g}$ & $\mathbf{2 0 m g}$ & $\mathbf{1 0 u g}$ & $\mathbf{1 0 u g}$ \\
\hline Citrobacter sp & NS & $10.0 \pm 0.4$ & $11.6 \pm 0.4$ & $15.4 \pm 0.5$ & $10.6 \pm 0.4$ \\
Enterobacter sp & NS & $10.0 \pm 0.0$ & $10.0 \pm 0.0$ & - & - \\
Escherichia coli & NS & - & - & $11.4 \pm 0.2$ & - \\
Staphylococcus aureus & NS & $16.6 \pm 0.2$ & $18.8 \pm 0.2$ & $26.6 \pm 0.2$ & $23.6 \pm 0.4$ \\
Enterococcus faecalis & NS & $11.4 \pm 0.5$ & $15.0 \pm 0.3$ & Nottested & - \\
Proteus mirabilis & NS & $10.6 \pm 0.2$ & $11.4 \pm 0.4$ & $29.6 \pm 0.4$ & $19.8 \pm 0.2$ \\
Proteus vulgaris & NS & $11.6 \pm 0.2$ & $13.0 \pm 0.0$ & $23.6 \pm 0.4$ & $29.4 \pm 0.4$ \\
Providencia sp & NS & - & & $39.8 \pm 0.2$ & $24.6 \pm 0.2$ \\
Alcaligenes sp & DS & $12.2 \pm 0.2$ & $13.6 \pm 0.2$ & $35.2 \pm 0.2$ & $17.6 \pm 0.2$ \\
Enterobacter sp & DS & $10.0 \pm 0.0$ & $10.0 \pm 0.0$ & - & - \\
Enterococcus faecalis & DS & $11.0 \pm 0.3$ & $12.0 \pm 0.4$ & Nottested & - \\
Escherichia coli & DS & $11.2 \pm 0.2$ & $12.6 \pm 0.2$ & $21.6 \pm 0.2$ & $11.8 \pm 0.2$ \\
Proteus vulgaris & DS & $11.4 \pm 0.2$ & $12.4 \pm 0.2$ & - & - \\
Pseudomonas aeruginosa & DS & $11.6 \pm 0.2$ & $12.6 \pm 0.2$ & $27.0 \pm 0.4$ & $15.4 \pm 0.2$ \\
Staphylococcus aureus & DS & $11.0 \pm 0.0$ & $11.6 \pm 0.2$ & $21.4 \pm 0.2$ & $16.4 \pm 0.4$ \\
CON Staphylococcus & ES & $16.2 \pm 0.2$ & $17.6 \pm 0.2$ & $24.0 \pm 0.8$ & $25.8 \pm 0.7$ \\
Klebsiella sp & ES & $11.6 \pm 0.2$ & $11.8 \pm 0.2$ & - & - \\
Proteus mirabilis & ES & $10.0 \pm 0.0$ & $12.4 \pm 0.2$ & $35.6 \pm 0.4$ & $30.0 \pm 0.0$ \\
Pseudomonas aeruginosa & ES & $11.8 \pm 0.2$ & $13.0 \pm 0.0$ & $36.6 \pm 0.2$ & $15.6 \pm 0.2$ \\
Staphylococcus aureus & ES & $16.2 \pm 0.5$ & $18.4 \pm 0.6$ & $20.5 \pm 0.3$ & $19.8 \pm 0.2$ \\
\hline
\end{tabular}

Note: $E S=$ infected eye; $D S=$ wound of diabetic patient; $N S=$ wound of non-diabetic patient; $C O N=$ coagulase negative; Cipro = ciprofloxacin; Gentam = gentamycin; - = no activity 
Table 3: Zone of inhibition $(\mathrm{mm})$ of bacterial isolates in agar treated with chloroform and aqueous fractions from the methanol extract of $N$. laevis stem bark (mean $\pm \mathrm{SD}$ )

\begin{tabular}{llll}
\hline Organism & Source & $\begin{array}{l}\text { Chloroform } \\
\text { fraction } \\
\mathbf{( 2 0} \mathbf{~ m g})\end{array}$ & $\begin{array}{l}\text { Aqueous } \\
\text { fraction } \\
\mathbf{( 2 0} \mathbf{~ m g})\end{array}$ \\
\hline Escherichia coli & $\mathrm{NS}$ & $10.7 \pm 0.3$ & 0 \\
Enterobacter sp & $\mathrm{NS}$ & 0 & 0 \\
$\begin{array}{l}\text { Staphylococcus } \\
\text { aureus }\end{array}$ & $\mathrm{NS}$ & $19.7 \pm 0.3$ & $19.7 \pm 0.3$ \\
$\begin{array}{l}\text { Staphylococcus } \\
\text { aureus }\end{array}$ & $\mathrm{DS}$ & $11.0 \pm 0.0$ & $14.0 \pm 3.0$ \\
$\begin{array}{l}\text { Enterococcus } \\
\text { faecalis }\end{array}$ & $\mathrm{DS}$ & $13.0 \pm 3.0$ & 0 \\
$\begin{array}{l}\text { Enterobacter sp } \\
\text { Escherichia coli }\end{array}$ & $\mathrm{DS}$ & $12.3 \pm 0.3$ & 0 \\
$\begin{array}{l}\text { Staphylococcus } \\
\text { aureus }\end{array}$ & $\mathrm{ES}$ & 0 & 0 \\
$\begin{array}{l}\text { Pseudomonas } \\
\text { aeruginosa }\end{array}$ & $\mathrm{ES}$ & $15.3 \pm 0.3$ & $13.0 \pm 0.0$ \\
$\begin{array}{l}\text { Proteus mirabilis } \\
\text { ES }\end{array}$ & $15.3 \pm 0.3$ & $14.7 \pm 0.3$ \\
\hline
\end{tabular}

$E S=$ infected eye; $D S=$ wound of diabetic patient; $N S=$ wound of non-diabetic patient

The MIC of $12.5 \mathrm{mg} / \mathrm{ml}$ could not produce complete elimination of the organism obtained from infected eye although a remarkable reduction in the viable cell count was obtained with $2 \mathrm{MIC}$ after the incubation period of $24 \mathrm{~h}$. Both the MIC and 2MIC indicated an initial kill or reduction in the viable cell counts followed by bacteriostatic effect (Fig. 2).

In all the concentrations of the Ciprofloxacin tested, the viable cell count of the two organisms significantly decreased below the control up to $6 \mathrm{~h}$ after which there was resistance to the drug indicated by the increase in the viable cell counts (results not shown).

\section{DISCUSSION}

Although the phytochemical and antimicrobial properties of $N$. laevis have been reported (7), a comparative study of the stem bark methanol extract on organisms isolated from wounds and infected eyes has not been considered. The predominance of the various organisms was observed to vary depending not only on the part of the body from which they were obtained but also on the physiological state of the subjects. While Staph. aureus and $P$. aeruginosa were observed to be predominant in the eye isolates, the organisms obtained from the wounds of diabetic and non-diabetic patients were dominated by Proteus and Staph. aureus, respectively. The extract and the organic solvent fractions were considered active at a zone of inhibition diameter of $\geq$ $10 \mathrm{~mm}^{[18,19]}$.

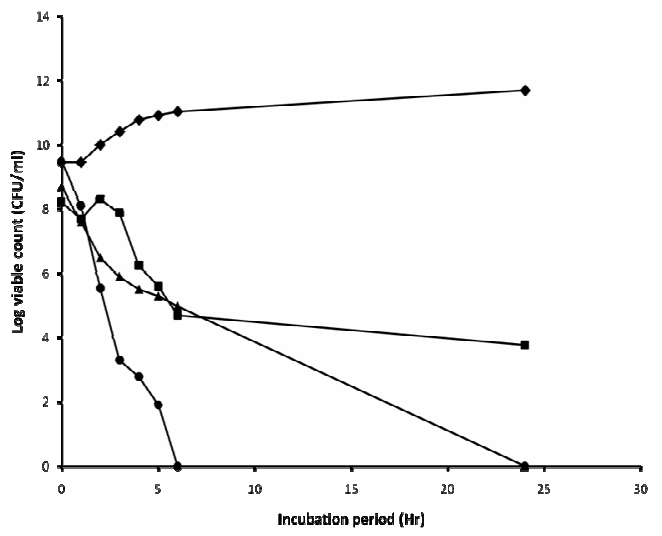

Fig 1: Time-killing effect of different concentrations of methanol extract of the stem bark of Newbouldia laevis on the viable count of Staphylococcus aureus (non-dibetic wound isolate, NS). Key: = control; $\mathbf{\square}=$ $1 / 2 \mathrm{MIC} ; \boldsymbol{\Delta}=\mathrm{MIC} ; \bullet=2 \mathrm{MIC}$

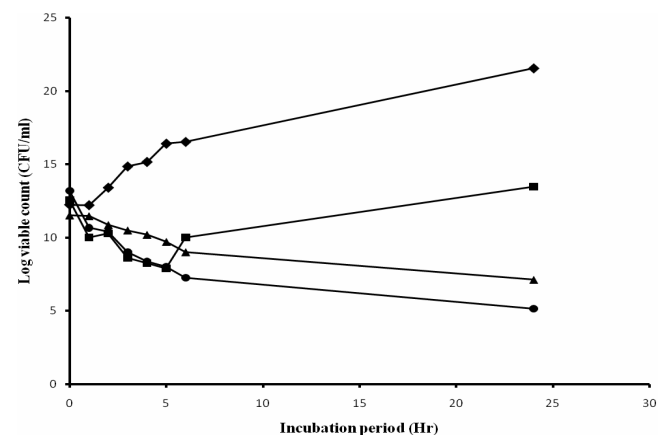

Fig 2: Time-killing effect of different concentrations of methanol extract of the stem bark of Newbouldia laevis on the viable count of Staphylococcus aureus (ES = eye isolate) Key: $\bullet=$ control; $\square=1 / 2$ MIC; $\Delta=$ MIC; $\bullet=2$ MIC 
Table 4: Minimum Inhibitory Concentration (MIC) and Minimum Bactericidal Concentration (MBC) of methanol extract of the stem bark $(\mathrm{mg} / \mathrm{ml})$ of Newbouldia laevis and of reference antibacterial agents

\begin{tabular}{|c|c|c|c|c|c|c|c|c|c|}
\hline \multirow[t]{2}{*}{ Bacterial isolate } & \multirow[t]{2}{*}{ Source } & \multicolumn{3}{|c|}{ Ciprofloxacin $(\mu \mathrm{g} / \mathrm{ml})$} & \multicolumn{3}{|c|}{ Gentamicin $(\mu \mathrm{g} / \mathrm{ml})$} & \multicolumn{2}{|c|}{ Extract $(\mathrm{mg} / \mathrm{ml})$} \\
\hline & & MIC & MBC & $\mathrm{MIC}$ ic & MIC & MBC & MIC ic & $\mathrm{MIC}$ & $\mathrm{MBC}$ \\
\hline Citrobacter sp & NS & 16 & 16 & $\mathrm{R}$ & 32 & 32 & $\mathrm{R}$ & 12.5 & 25 \\
\hline Enterobacter sp & NS & $>16$ & $>16$ & $\mathrm{R}$ & 32 & $>32$ & $\mathrm{R}$ & 12.5 & 12.5 \\
\hline Escherichia coli & NS & $>16$ & $>16$ & $\mathrm{R}$ & $>32$ & $>32$ & $\mathrm{R}$ & 25 & 50 \\
\hline Proteus mirabilis & NS & $<0.03$ & 0.5 & $\mathrm{~S}$ & 4 & 4 & $\mathrm{~S}$ & 12.5 & 25 \\
\hline Proteus vulgaris & NS & 16 & $>16$ & $\mathrm{R}$ & 8 & 16 & $\mathrm{R}$ & 3.125 & 6.25 \\
\hline Providencia sp & NS & $<16$ & $\geq 16$ & $\mathrm{R}$ & $<2$ & $\geq 2$ & $\mathrm{~S}$ & 12.5 & 25 \\
\hline Staphylococcus aureus & NS & 1 & $>1$ & $\mathrm{~S}$ & 4 & 4 & $\mathrm{R}$ & 6.25 & 12.5 \\
\hline Enterococcus faecalis & NS & NT & NT & NT & 32 & 32 & $\mathrm{R}$ & 3.125 & 6.25 \\
\hline Alcaligenes sp & DS & $<0.5$ & $\geq 0.5$ & $\mathrm{~S}$ & $>4$ & $>4$ & $\mathrm{R}$ & 6.25 & 12.5 \\
\hline Enterobacter sp & DS & $>16$ & $>16$ & $\mathrm{R}$ & $>32$ & $>32$ & $\mathrm{R}$ & 12.5 & 25 \\
\hline Escherichia coli & DS & $>1$ & $>1$ & $\mathrm{R}$ & $>32$ & $>32$ & $\mathrm{R}$ & 6.25 & 12.5 \\
\hline Proteus vulgaris & DS & $>16$ & $>16$ & $\mathrm{R}$ & $>32$ & $>32$ & $\mathrm{R}$ & 6.25 & 12.5 \\
\hline Pseudomonas aeruginosa & DS & $<0.5$ & $\geq 0.5$ & $\mathrm{~S}$ & $>4$ & $>4$ & $\mathrm{R}$ & 3.125 & 12.5 \\
\hline Staphylococcus aureus & DS & $<0.5$ & $\geq 0.5$ & $\mathrm{~S}$ & $<1$ & $\geq 1$ & $\mathrm{~S}$ & 6.25 & 12.5 \\
\hline Enterococcus faecalis & DS & NT & NT & NT & $>256$ & $>256$ & $\mathrm{R}$ & 12.5 & 25 \\
\hline CON Staph. & ES & 0.5 & 1 & $S$ & 1 & 2 & $S$ & 3.125 & 6.25 \\
\hline Klebsiella sp & ES & $>16$ & $>16$ & $\mathrm{R}$ & $>32$ & $>32$ & $\mathrm{R}$ & 12.5 & 12.5 \\
\hline Proteus mirabilis & ES & 1 & $>1$ & $S$ & $>32$ & $>32$ & $\mathrm{R}$ & 6.25 & 6.25 \\
\hline Pseudomonas aeruginosa & ES & $>4$ & $>4$ & $\mathrm{R}$ & $>32$ & $>32$ & $\mathrm{R}$ & 12.5 & 25 \\
\hline Staph. aureus & ES & 0.5 & 1 & S & 8 & 8 & $\mathrm{R}$ & 12.5 & 12.5 \\
\hline
\end{tabular}

$R=$ resistant; $S=$ susceptible; $N T=$ not determined; $E S=$ infected eye; $D S=$ wound of diabetic patient; NS = wound of non-diabetic patient

The extract showed remarkable activities against both the Gram-negative and Grampositive bacteria. The Gram-negative bacterial organisms are generally regarded more difficult to inhibit due to the presence of a thick murein layer that tends to prevent the entry of inhibitors ${ }^{[20,21]}$. However, the extract of $N$. laevis inhibited some Gram-negative bacteria such as Enterobacter and Klebsiella species both at 10 and $20 \mathrm{mg}$. It is remarkable to note that Staphylococci which have a record of developing resistance rapidly and successfully to antibiotics ${ }^{[22]}$ were the most susceptible to the methanol stem bark extract. The E. coli and Providencia (obtained from the wounds of non diabetic patients) specie which earlier exhibited resistance to the extract at $20 \mathrm{mg}$ were observed to have MIC and MBC of 25 and 50 $\mathrm{mg} / \mathrm{ml}$. These indicated that the concentrations used earlier were grossly ineffective in subduing the growth of the organisms. Also, based on these higher MIC and $\mathrm{MBC}$ than others, the two organisms being Gram negatives can be said to be the most resistant to the extract.

The times required to reduce or eliminate Staph. aureus isolates from non-diabetic and infected eyes showed some variation probably due to variations in the sources of the organisms. From the results, the isolate obtained from the wounds of non-diabetic subjects was eliminated completely in less than $6 \mathrm{~h}$ at twice the MIC and $24 \mathrm{~h}$ at the MIC; although there was no total elimination of the isolate obtained from the eye, the extract showed pronounced reduction in the population of the organism at two times the MIC. The susceptibility exhibited by the microorganisms to the extract as well as the aqueous and chloroform fractions may be attributed to the presence of different groups of constituents that may be acting synergistically with one another. Partitioning plant extracts in two immiscible solvents enables the separation of the plant active constituents with the eventual aim of locating where the active constituents could be residing. In this work, the results obtained 
show that the constituents of the extract were responsible for the observed antibacterial activities and it is important to note that, for some of the organisms, the inhibitory effects became more pronounced for the organic solvent fraction. The overall observed antibacterial activities of the extracts could be traced to the presence of the secondary metabolites like tannins, alkaloids, flavonoids reported present in the plant material. The results of this work have justified the ethnomedicinal claim of the stem bark of $N$. laevis in treating septic wounds and infected eyes.

\section{CONCLUSION}

The results obtained in this work indicate that the stem bark of $N$. laevis possesses natural potential to inhibit the growth of various organisms. The observed antibacterial effects may due to the presence of secondary metabolites in the plant. Our findings justify the ethnomedicinal claim of the stem bark of $N$. laevis in treating septic wounds and infected eyes.

\section{REFERENCES}

1. Hutchinson J, Dalziel JM. Flora of West Tropical Africa vol II. London: Crown Agents for Oversea Government and Administration, 1963; pp 435-436.

2. Arbonnier M. Trees, Shrubs and Lianas of West African Dry Zones. CIRAD, Margraf Publishers, GMBH MNHN, Cote d'Ivoire, 2004; p 194.

3. Iwu MM. Handbook of African Plants. London: CRC Press, Inc, 2000; $p 19$.

4. Gorman R, Kaloga M, Ferreira D, Bergenthai $D$, Kolodziej $H$. Furanonaphthoquinones, atracic acid and a benzofuran from the stem bark of Newbouldia laevis. Phytochem. 2003; 64: 583-587.

5. Eyong OK, Krohn $K$, Hussain $H$, Folefoc NG, Nkengfack $A E$, Schulz $B, H u$ $Q$. Newbouldiaquinone and newbouldiamide: $A$ napthoquinone-anthraquinone couple and a new ceramide from Newbouldia laevis. Chem. Pharm Bull 2005; 53: 616-619.

6. Gill LS. Ethnomedical uses of plants in Nigeria. University of Benin Press, Benin City, 1992; pp 174-175.

7. Usman $H$, Osuji JC. Phytochemical and in vitro antimicrobial assay of the leaf extract of
Newbouldia laevis. Afr J Trad Compl \& Alt Med 2007; 4(4): 476-480.

8. Chukwujeku JC, Staden JV, Smith P. Antibacterial, anti-inflammatory and antimalarial activities of some Nigerian medicinal plants. SA J Bot 2005; 71 (3\&4): 316-325.

9. Germann $K$, Kaloga M, Ferreira $D$, Marais JP, Kolodziej H. Newbouldioside A-C Phenylethanoid Glycosides from the stembark of Newbouldia leavis. Phytochem 2006; 67(8): 805-811.

10. Edwards R, Harding KG. Bacteria and wound healing. Curr Opin Infect Dis 2004; 17(2): 91 96.

11. Anton CD, Andries GG, Hermien G. Common eye disorders. In: Eric Herfindal T, Dick Gourlry R, editors. Textbook of Therapeutics: Drug and Disease Management, $6^{\text {th }}$ edition, Williams and Wilkins, USA, 1996; p 937.

12. Al-Bayati FA, Al-Mola HF. Antibacterial and antifungal activities of different parts of Tribulus terrestris L. growing in Iraq. $J$ Zhejiang Univ. Sci. B 2008; 9(2): 154-159.

13. Evans WC. Pharmacognosy. $15^{\text {th }}$ edn. London: Saunders Publishers, 2002; pp 246-249.

14. Sofowora A. Medicinal Plants and Traditional Medicine in Africa. John Wiley, Chichester, 1982; pp 142-146.

15. Cheesbrough $M$. District laboratory practice in tropical countries. Part 2. Cambridge University Press, 2000; pp 63-70.

16. Collins CH, Lynes PM, Grange JM. Microbiological Methods ( $7^{\text {th }}$ Edn.) Butterwort-Heinemann Ltd., Britain, 1995; pp 175-190.

17. Zgoda JR, Porter JR. A convenient microdilution method for screening natural products against bacteria and fungi. Pharm Biol 2001; 39: 221 225.

18. Zwadyk P. Enterobacteriaceae in Zinsser Microbiology. $20^{\text {th }}$ Ed. George Thiene Verlag, Stuttgart, 1972; pp 20-32.

19. Usman H, Haruna AK, Akpulu IN, Ilyas M, Ahmadu $A A$, Musa YM. Phytochemical and antimicrobial screenings of the leaf extract of Celtis integrifolia Lam. J. Trop. Biosci. 2005; 5 (2): 72-76.

20. Martin G. Ethnobotany: a Methods Manual. London: Chapman and Hall, 1995, p 80.

21. Vlietinck AJ, Van Hoof L, Totte J, Lasure A, Berghe VD, Rwangabo PC, Mwakiyumwani J. Screening of a hundred Rwandese medicinal plants for antibacterial and antiviral properties. J. Ethnopharmacol. 1995;46:31-47

22. Kloos WE. Resistance of Staphylococcus to antimicrobial agents. In: Balows A, Duerden $B$, Eds. Topley and Wilson's Microbiology and Microbial Infections, Systematic Bacteriology Vol 2,. 1998; pp 602-612. 